ical Science Association, and participated on other committees in both organizations. He was a founding member of the British Politics Group, an organization which he also served as president and as a longtime member of the Executive Committee. He also participated on committees of the National Science Foundation and Fulbright-Hays Program.

Jim's scholarly interests were diverse, including political culture, public policy, public administration, and foreign policy. An edited book, Cases in Comparative Politics, first published in 1965 , went through three editions, the latter two coedited with Bernard E. Brown. Britain at the Crossroads was published by the Foreign Policy Association in 1967. His major scholarly book, Capital Punishment and British Politics (1962), has had a considerable long-term impact on political science. It posed the question of how a supposedly responsible twoparty system with strong executive leadership could find this issue so difficult to resolve and contrary to usual parliamentary procedures. Examining Western democracies more broadly, a former student of his at Ohio State, T. Alexander Smith, synthesized the findings of his book with the policy classification scheme of Theodore Lowi in The Comparative Policy Process. Raymond Tatalovich and Byron Daynes later analyzed United States politics in similar terms in Social Regulatory Policy. A considerable amount of subsequent work has argued that a comprehensive theory of public policy must also include nonsocioeconomic issues in which different institutional procedures are followed, including a weakening of normal lines of party and ideology in favor of appeals to a legislator's conscience and constituents' wishes. A recent article in the British Journal of Political Science cites Jim's book several times as a foundation of research on parliamentary free votes. Thus work in at least three areas-comparative politics, public policy, and legislative behavior-has been influenced to the present by this theoretically-informed study of one policy issue in one country.
Jim's paper, "Consensus and Cleavage in British Political Ideology," which won the Pi Sigma Alpha Award for the Best Paper presented at the 1964 Annual Meeting of the American Political Science Association, was published in 1965 in the $A P S R$, and was reprinted in several widely used comparative politics readers. Other published papers appeared in the Western Political Quarterly, Midwest Journal of Political Science, and Public Administration Review, among other journals on both sides of the Atlantic. Jim was also a prolific reviewer of books for scholarly journals. After his official retirement in 1992, he continued to be professionally active and to publish.

Jim Christoph worked diligently on behalf of graduate students at Indiana, whether they were immediately under his tutelage or not. If there were jobs, scholarships, grants, or awards and honors for which they might be eligible, Jim arranged to nominate them. He was also generous with introductions to his colleagues in the United Kingdom. As a mentor, he was encouraging, positive, and rigorous. He was equally attentive to undergraduate needs. After three years as director of undergraduate studies in political science, he served as director of learning support services for the Undergraduate Life Division at Indiana between 1981 and 1984. Much of what the four of us know about the art of university teaching we learned from Jim, who persuaded by example, not by exhortation. His courses were popular for the right reasons. Jim's good and upbeat nature was apparent when he was in front of the classroom.

As a professional, he was someone who generated respect from colleagues through his sound scholarship, conscientious teaching, and enthusiastic university citizenship. Jim served in many positions at Indiana and received particular accolades for his teaching, the Distinguished Teaching Award in 1980, and for his service, the Distinguished Faculty Service Award in 1988.

When one of us visited Jim near the end of his life, the conversation was of books, British politics, his last graduate student winning the Beer Award, the lives of his children, and what recent graduates were doing. Fully aware of the circumstances of his deteriorating health, he reflected on his short future on this earth. As ever, Jim was true and valiant, funny and life-affirming, kind and generous.

Despite all of his professional activities, well beyond the call of duty in many instances, Jim found time to accompany his wife Natalie in raising a family of five children and challenging visitors to their household to tennis competition. The sense of loss, but also the comfort of a life well lived, keenly felt by his family, is shared by the wider academic and other communities with which he was associated. Jim Christoph wore many hats-scholar, mentor, husband, father, friend. In all of these roles he displayed compassion and decency. As a person, Jim was a rare combination of dignity and pleasantness. Jim Christoph was, in fact, the very definition of the gentleman scholar.
Michael Jogerst
University of Chicago Jeffrey Pickering
Kansas State University Donley T. Studlar
West Virginia University Jerold L. Waltman
University of Southern Mississippi

\section{Robert Howe Connery}

It is with deep sadness that we report the death on July 3, 1998, at age 90, of Robert Howe Connery, our colleague, friend, and, for one of us, our teacher.

Connery was born in St. Paul, Minnesota, and graduated from the University of Minnesota in 1929. After receiving his master's degree there in 1930, he went on to Columbia to earn his doctorate in 1935. He served as a naval officer and historian of the office of Secretary of the Navy James V. Forrestal during World War II, and eventually attained the rank of commander. After the war, Connery taught at several universities-Catholic University of America, Stanford, University of Illinois, and Duke- 
before settling at Columbia University, where he remained as a professor of government from 1966 until his retirement in 1979 . In the $1950 \mathrm{~s}$, he also served as a senior staff member for the Brookings Institution, where he conducted surveys of foreign affairs, NATO, and the United Nations.

As a graduate instructor, Professor Connery maintained a very focused approach in advising students. He tried to concentrate on producing Ph.D.s who knew their institutions, their history, and their politics, and who engaged in research that had an impact on the world. Professor Connery also served as a model of how to be both a professor and a gentleman. For him, the earned title "professor" was preeminent: "Only use 'doctor' on your checks, or to get a table at a restaurant," he advised. "This is Professor Connery," he announced when he got on the phone.

To those who were close to him, however, Professor Connery acted in a capacity that extended far beyond that of instructor. His titles could have also included those of confessor, patron saint, cheerleader, critic, financial advisor, and closest admirer. Professor Connery was a bachelor and after his mother died had no family. Thus, when a student or researcher studied with Connery, that student became family, and remained so ever after - a fact Connery would reaffirm in many different ways.

Professor Connery served as the president of the Academy of Political Science from 1966 to 1986 , during which time he edited some 40 volumes of its proceedings. His own writings ranged widely over federal, state, and local government issues. Among the many books that he authored, coauthored, and edited is a classic study, Rockefeller of New York: Executive Power in the Statehouse. His Navy experiences prompted him to write Forrestal and the Navy, with Robert G. Albion. This book addressed Forrestal's years in the Navy Department, a time characterized by the rapid expansion of the American Navy and a successful battle to keep the Air Force from taking control of naval air. The interest provoked by his doctoral dissertation, "Governmental Problems in Wildlife Conservation," led to his work as a government consultant in a disagreement between New York and New Jersey over shad fisheries in the Hudson River.

Professor Connery also served as deputy city administrator under Mayor Robert F. Wagner in 1965. He had previously acted as a senior consultant to the State Commission on Governmental Operations of the City of New York and executive secretary of the city's Committee on Modern Zoning. Indeed, city administrators continued to consult with him for some time after his retirement from Columbia in 1976.

Although Robert Connery leaves no immediate survivors, he will live on through his rich legacy of written works, civic achievements, and many friendships. He lived a full life, enjoying good health and mental alertness up until the final months of his ninety years.

Gerald Benjamin State University of New York, New Paltz Demetrios James Caraley Barnard College, Columbia University

\section{C.N. Fortenberry}

Charles Nolan Fortenberry died on May 10, 1998, at the age of 89. He made major contributions to the institutions of the University of Mississippi and Auburn University. Recognition of his impact on faculty and students in those two states over more than three decades of teaching, research, and administration have been acknowledged by the establishment of programs of awards named in his honor at both institutions.

Most of his education took place during the Depression. After completing high school in his native town of Oak Vale, Mississippi, he journeyed north to the University of Mississippi, where he earned both his baccalaureate and masters degrees. This achievement was followed by teaching social science in high schools at Oak Vale and Clinton, Mississippi. From there, he proceeded toward the doctoral degree at the University of Illinois, where he held the post of graduate teaching assistant. While he was at the University of Illinois, he not only obtained a Ph.D. in political science but he also met a candidate for a masters degree in French, Mary Edwards, and married her.

After he earned the Ph.D. in political science, he began his teaching experiences in higher education: Edinburg College as instructor in government, Texas A\&M College as assistant professor, and North Texas State College as assistant professor and then associate professor of government. After serving to the rank of captain in the USA Air Corps, he returned to the University of Mississippi as associate professor and then professor of political science. He eventually rose to the rank of Lieutenant Colonel in the USAF Reserve.

After his colleague Robert B. Highsaw left for the University of Alabama, Nolan Fortenberry was asked to head up the department of research in business and public administration, even though neither was one of his specialties. In 1957 he served as acting dean of the graduate school while the incumbent dean was on sabbatical. In 1958 he became chair of the department of political science, a post he held until 1968.

His tenure as department chair covered the most stormy years of Ole Miss' history, largely involving race relations. He took many personal attacks for his commitment to the U.S. Constitution and his attempts to heal the wounds of the long-building conflict. The forced admission of James Meredith - an African-American, honorably discharged veteran - as a political science major in 1962 intensified these attacks. He also had to face up to the beginning of episodes by a faculty member who had a bipolar disease.

Nolan's colleague, Edward H. Hobbs, moved to Auburn University as dean of arts and sciences in 1967, and in 1968 he asked Nolan to come to Auburn to help get the new department of political science started. Once again, Nolan's administrative acumen was recognized. His philosophy was: "Hire someone good and 